\title{
Functional implications of the utero-placental relaxin (RLN) system in the dog throughout pregnancy and at term
}

\author{
Marta Nowak¹, Aykut Gram, Alois Boos, Selim Aslan², Serhan S Ay², Firdevs Önyay ${ }^{3}$ and \\ Mariusz P Kowalewski ${ }^{1}$ \\ ${ }^{1}$ Institute of Veterinary Anatomy, Vetsuisse Faculty, University of Zurich, Zurich, Switzerland, ${ }^{2}$ Department of \\ Obstetrics and Gynecology, Veterinary Faculty, Near East University, Nicosia, North Cyprus, Turkey and \\ ${ }^{3}$ Department of Obstetrics and Gynaecology, Faculty of Veterinary Medicine, University of Ondokuz Mayis, \\ Samsun, Turkey \\ Correspondence should be addressed to MP Kowalewski; Email: kowalewskipl@yahoo.de
}

\begin{abstract}
Relaxin (RLN) is a key hormone of pregnancy in mammals best known for its involvement in connective tissue remodeling. In the domestic dog, placental RLN is the only known endocrine marker of pregnancy. However, knowledge is sparse regarding the spatio-temporal expression of RLN and its receptors (RXFP1 and RXFP2) in the canine uterus and placenta. Here, their expression was investigated in the pre-implantation uterus and utero-placental compartments (UtPI) at selected time points during gestation: post-implantation, mid-gestation, and at normal and antigestagen-induced luteolysis/abortion. Immunohistochemistry with newly generated, canine-specific antisera, in situ hybridization and semi-quantitative PCR were applied. In compartmentalization studies, placental and endometrial $R L N$ increased continuously toward prepartum. The placental $R X F P 1$ was time-related and highest during post-implantation and decreased together with RXFP2 at prepartum luteolysis. The endometrial levels of both receptors did not vary greatly, but myometrial RXFP2 decreased from mid-gestation to prepartum luteolysis. Antigestagen treatment resulted in suppression of $R L N$ in UtPI and decreased RXFP1 and RXFP2 in the uterus. The placental RLN was localized mainly in the cytotrophoblast. Additionally, RXFP1 stained strongly in placental endothelial cells while RXFP2 was found mainly in maternal decidual cells. Uterine staining for all targets was found in epithelial cellular constituents and in myometrium. Finally, besides its endocrine functions, RLN seems to be involved in auto-/paracrine regulation of utero-placental functions in dogs in a time-dependent manner. New insights into feto-maternal communication was provided, in particular regarding the localization of RXFP2 in the maternal decidual cells, implying functional roles of RLN during the decidualization process.

Reproduction (2017) 154 415-431
\end{abstract}

\section{Introduction}

Relaxin (RLN) is an approximately $6-\mathrm{kDa}$ polypeptide regarded as an indispensable hormone during pregnancy and at parturition in many mammalian species. It mediates various processes during gestation and at parturition. Its best known function is in remodeling the pubic symphysis, thereby increasing its flexibility and facilitating the transport of fetuses at parturition (Hisaw 1926, Zhao et al. 1999). Furthermore, e.g., in women, RLN was reported to promote endometrial thickening and vascularization, in order to facilitate early embryo implantation (Unemori et al. 1999). Due to its functions in remodeling connective tissue, RLN is also known to be a crucial factor involved in growth and softening of the uterine cervix during pregnancy (Downing \& Sherwood 1986, O'Day-Bowman et al. 1991). In several species, e.g., in the rat, mouse and pig, it is known to promote uterine quiescence (Wiqvist 1959, Griss et al. 1967,
Khaligh 1968, Porter 1971, MacLennan et al. 1986). In addition, trophic effects of RLN were described on the mammary gland in pigs (Min \& Sherwood 1996) and on the nipples in rodents (Hwang et al. 1991, Zhao et al. 1999). There is also evidence that RLN contributes to pregnancy-related cardiovascular changes by affecting the functionality of blood vessels, heart and kidneys (Novak et al. 2001, Debrah et al. 2006).

As a member of a relaxin-like family, RLN is synthesized as a preprohormone with signal sequence and characteristic B-C-A structure (Sherwood 2004, Bathgate et al. 2006a). Subsequently, during posttranslational modification, the $\mathrm{C}$-chain is removed and mature RLN consists only of the B- and A-chains. Although RLN shows great sequence divergence among species, twelve amino acids are highly conserved in mammals. Among these are six cysteine residues, which form three disulfide bonds: two inter-chain bonds connecting the B and A-chains, and one intra-chain 
bond located in the A-chain. Also, in the middle of the B chain, the amino acid motif Arg-X-X-X-Arg-X-X-Ile/Val is located, which is required for binding to receptors and ensuring RLN bioactivity. RLN interacts with receptors that belong to the family A of G-protein coupled receptors (GPCRs) (Bathgate et al. 2013). Specifically, RLN may bind to two receptors, RXFP1 and RXFP2. Both are members of the leucine-rich repeat-containing GPCR (LGR) subfamily that also includes receptors for follicle stimulating hormone $(\mathrm{FSH})$ and luteinizing hormone $(\mathrm{LH})$. It is noteworthy that both receptors are the only human GPCRs that possess the low-density lipoprotein class A (LDLa) module (Bathgate et al. 2006b), which is essential for receptor signaling. RLN binds with the highest affinity to RXFP1, however, it can also crossreact with and strongly activate RXFP2 (Hsu et al. 2002).

The sources and profiles of RLN levels during pregnancy vary among species, and its origin does not coincide with the primary P4 source in many species (reviewed in Bathgate et al. 2006a). Nevertheless, possible direct relationships between P4 and RLN secretion cannot be excluded. While in some animals (i.e., pigs and rodents), RLN and P4 originate from the same tissue, i.e., corpus luteum $(\mathrm{CL})$ (Anderson \& Sherwood 1984, Anderson et al. 1984, Fields \& Fields 1985), in others, like the dog, rabbit and golden hamster that rely on $\mathrm{CL}$ as the main source of P4, RLN originates from the placenta (Eldridge \& Fields 1985, Renegar et al. 1987, Tsutsui \& Stewart 1991). Similarly, in women circulating RLN is synthesized in the CL (Stoelk et al. 1991). Finally, RLN can also be produced by the uterine endometrial glands as observed in guinea pigs (Pardo \& Larkin 1982). Therefore, due to the variety of RLN effects during pregnancy, and its secretory patterns and physiology in different species, RLN is considered to be one of the most diverse, unique polypeptide hormones.

In the domestic dog (Canis lupus familiaris), luteal P4 is required for the entire duration of gestation because the canine placenta lacks any steroidogenic activity (Hoffmann et al. 1994, Nishiyama et al. 1999); it is notable that the dog is the only domestic animal species devoid of placental steroids. Moreover, P4 profiles are similar in pregnant and non-pregnant cyclic bitches. Only shortly before parturition, around Day 60 of gestation, a steep decrease in P4 is observed, signaling the onset of active prepartum luteolysis (Concannon 2011). Furthermore, there is no pregnancy and/or parturition-related elevation of E2 levels in the dog (Hoffmann et al. 1994, Onclin et al. 2002). Therefore, neither P4 nor E2 can serve as a marker of pregnancy in this species. Attempts to establish other reliable markers of pregnancy, e.g., by measurements of some acute phase proteins like fibrinogen or serum amyloid A, have failed (Vannucchi et al. 2002, Ulutas et al. 2009). Consequently, placental RLN is regarded, so far, as the only available marker of pregnancy in the dog. Originating from the placenta (Tsutsui \& Stewart 1991), canine RLN starts to increase around Days 25-30 after the LH surge, peaks at around Day 35 of gestation and remains elevated until labor, after which it decreases within 1-2 days to undetectable levels (Steinetz et al. 1987, 1989, Gunzel-Apel et al. 2006). Whereas numerous studies investigated blood levels of RLN during canine pregnancy (Steinetz et al. 1987, 1989, Gunzel-Apel et al. 2006, Schafer-Somi et al. 2007), very little is known about the uterine and placental localization and expression of the RLN-system (i.e. RLN and its two receptors: RXFP1 and RXFP2) throughout canine gestation. Moreover, endocrine regulatory mechanisms regulating the expression and function of the RLN-system remain underinvestigated. Therefore, aiming to fill the existing knowledge gap, here the spatio-temporal expression and localization of RLN, RXFP1 and RXFP2 were investigated in the canine uterus and placenta at selected time points during pregnancy, starting with the pre-implantation period, and at normal and antigestagen-induced parturition. Both, RNA and protein expression patterns were determined, the latter using canine-specific, custom-made antibodies.

\section{Materials and methods}

\section{Tissue collection and preservation}

Tissue materials from healthy, crossbreed bitches, aged 2-8 years, were collected by ovariohysterectomy (OHE). The samples included utero-placental compartments (UtPl; uterus with adjacent placenta) and interplacental uterine sites (IntPI; uterine wall between attachment sites) allotted to four study groups, representing the following stages: pre-implantation (Days $8-12, n=5$ ), post-implantation (Days 18-25, $n=5$ ), mid-gestation (Days 35-40, $n=5$ ) and prepartum luteolysis $(n=3)$. No IntPl tissue material from prepartum luteolysis was available for the study. In addition, to terminate pregnancy, the antigestagen aglepristone (Alizine, Virbac, Bad Oldesloe, Germany; at a dose of $10 \mathrm{mg} / \mathrm{kg}$ bw; $2 \times / 24 \mathrm{~h}$ apart) was administered to mid-pregnant dogs (Days 40-45 of pregnancy, $n=10)$. OHE was performed $24 \mathrm{~h}(n=5)$ and $72 \mathrm{~h}(n=5)$ after the second treatment.

For all animals, the day of mating was assigned as Day 0 of pregnancy, and was 2-3 days after ovulation, which was determined by measurements of peripheral serum P4 levels reaching $>5 \mathrm{ng} / \mathrm{mL}$ and vaginal cytology. The pre-implantation group was specified by the presence of embryos flushed from uteri. Corresponding samples from dogs negative for embryo flushing were used as negative controls in the comparison investigating effects of early embryo presence on uterine expression of target genes (non-pregnant group, $n=8$ ). The prepartum luteolysis stage was confirmed by a decrease of peripheral P4 below $2-3 \mathrm{ng} / \mathrm{mL}$ in three consecutive measurements $6 \mathrm{~h}$ apart ( $\mathrm{P} 4$ serum levels were monitored every $6 \mathrm{~h}$ starting from gestation Day 58). The corresponding P4 concentrations during pregnancy and at normal and induced luteolysis, including downregulation of the steroidogenic machinery at the termination of luteal function, were reported previously (Kowalewski et al. 2009, 2010). 
All animal experiments were in accordance with animal welfare legislation (permits no. II 25.3-19c20-15c Gl 18/14 and VIG3-19c-20/15c GI 18,14 from Justus-Liebig University, Giessen, and permits no. Ankara 2006/2006 and 2008-25-124 from Faculty of Veterinary Medicine, University of Ankara). Following surgery, UtPI units and IntPI samples were carefully separated from surrounding tissues, fixed overnight with $10 \%$ neutral phosphate-buffered formalin at $+4^{\circ} \mathrm{C}$ and subsequently incubated with phosphate-buffered saline for 1 week, replacing with fresh buffer every $24 \mathrm{~h}$. Afterwards, tissue material was dehydrated in a graded ethanol series, embedded in paraffinequivalent Histo-Comp (Vogel, Giessen, Germany), and finally used for immunohistochemistry (IHC) and non-radioactive in situ hybridization (ISH).

For total RNA extractions, tissue samples were placed in RNAlater (Ambion Biotechnology $\mathrm{GmbH}$, Wiesbaden, Germany), using the ratio mass:volume 1:6, incubated for $24 \mathrm{~h}$ at $+4^{\circ} \mathrm{C}$ and subsequently stored at $-80^{\circ} \mathrm{C}$ until isolation.

\section{Homology cloning of canine-specific relaxin/insulin-like family peptide receptor 1 (RXFP1) sequence}

The canine-specific RXFP1 had not been characterized previously. Thus, prior to investigating its mRNA expression and localization patterns, molecular cloning and sequencing were performed. Using online available predicted sequences of canine RXFP1, three consensus pairs of primers were selected, designed and ordered from Microsynth AG (Balgach, $\mathrm{CH}$ ) to produce overlapping cDNA products: forward-1: 5'-ACG GAT GGC CTT TGC AAT TT-3'; reverse-1: 5'-CCT TAA ACA CTT GCG GTG GA-3'; forward-2: 5'-TTG CGG TAA TTT AAC TGT TTT GGT-3'; reverse-2: 5'-TGC ACT TTC TGG GTC TTA AAC A-3'; forward-3: 5'-TGT CCA CTG AAG TAT CCG TGT-3'; reverse-3: 5'-GCA TCT CAC AAT ATT CTC CGT GT-3'. Hot start PCR was carried out using the GeneAmp Gold RNA PCR Kit (Applied Biosystems by Thermo Fischer) with annealing temperature set for $60^{\circ} \mathrm{C}$ in accordance with our previously described protocol (Kowalewski et al. 2006b, 2011b). Three overlapping amplicons encoding for canine RXFP1 were generated using total RNA from at least 3 utero-placental compartments and spanning 753, 773 and $841 \mathrm{bp}$, including the open reading frame; the total length of the amplified canine RXFP1 fragment was $2125 \mathrm{bp}$. Autoclaved water instead of cDNA and the so-called RT-minus control were used as negative controls. Following separation on $2 \%$ agarose gel stained with ethidium bromide, PCR products were purified using the QIAquick Gel Extraction Kit II (Qiagen). Next, they were ligated into a pGEM-T vector (Promega), transformed and amplified in XL1 Blue competent cells (Stratagene). Using Pure Yield Plasmid MiniPrep System (Promega), bacterial plasmids were purified and subjected to sequencing on both strands with T7 and SP6 primers (Microsynth). Finally, the cloned sequence was submitted to GenBank with the following accession number: KY980750.

\section{Total RNA extraction, semi-quantitative real-time TaqMan PCR (qPCR) and data evaluation}

The extraction of total RNA from UtPI units and IntPI sites was done using TRIzol reagent (Invitrogen) according to the manufacturer's protocol. RNA concentrations were measured with a NanoDrop 2000C spectrophotometer (Thermo Fisher Scientific AG). RQ1 RNase-free DNase (Promega) was used for DNase treatment to eliminate genomic DNA contamination, following the supplier's instructions. Subsequently, the reverse transcription (RT) reaction, using random hexamers as primers, was performed with reagents purchased from Applied Biosystems by Thermo Fisher using the previously published protocol (Kowalewski et al. 2006b, 2011a). For each sample, cDNA corresponding to $100 \mathrm{ng}$ of DNase-treated total RNA was used per run. Reactions were carried out in an Eppendorf Mastercycler (Vaudaux-Eppendorf AG, Basel, Switzerland).

An automated fluorometer ABI PRISM 7500 Sequence Detection System (Applied Biosystems) was used for all semi-quantitative analyses of RLN-, RXFP1- and RXFP2mRNA expression in canine UtPI units, IntPI samples and in separately dissected utero-placental compartments from postimplantation, mid-gestation and prepartum luteolysis groups.

For $\mathrm{UtPI}$ and IntPI units the $25 \mu \mathrm{L}$ reaction mixture consisted of: $200 \mathrm{nM}$ TaqMan Probe, $300 \mathrm{nM}$ of each primer, $12.5 \mu \mathrm{L}$ Fast Start Universal Probe Master (ROX) (Roche Diagnostics) and $5 \mu \mathrm{L}$ of cDNA corresponding to $100 \mathrm{ng}$ total RNA. Duplicates of each sample were run in 96-well optical plates (Applied Biosystems). Autoclaved water and the so-called minus-RT controls (i.e., samples treated with DNase but not subjected to RT) instead of cDNA were used as negative controls.

In all qPCR experiments the conditions for amplification were set as follows: initial denaturation for $10 \mathrm{~min}$ at $95^{\circ} \mathrm{C}$, followed by 40 cycles for $15 \mathrm{~s}$ at $95^{\circ} \mathrm{C}$ and $1 \mathrm{~min}$ at $60^{\circ} \mathrm{C}$. The expression levels of target genes were normalized according to three reference genes: GAPDH, B-ACTIN and CYCLOPHILIN $A$ and calculated using the comparative CT method $(\triangle \triangle C T$ method) according to the ABI 7500 Fast Real-Time PCR System protocol provided by the manufacturer and as described previously (Kowalewski et al. 2006b, 2011a). The efficiencies of the PCR assays were determined by the CT slope method assuring approximately $100 \%$ reaction efficiency. Based on the published canine CDS sequences, primers and TaqMan probes labeled with 6-carboxyfluorescein (6-FAM) and 6-carboxytetramethylrhodamine (TAMRA) were designed with Primer Express Software ver. 2.0 (Applied Biosystems) and purchased from Microsynth (Balgach, Switzerland). Canine-specific primers and probe mixtures for B-ACTIN (Prod. No. Cf03023880_g1) and CYCLOPHILIN A (Prod. No. Cf03986523-gH) were purchased from Applied Biosystems. A complete list of primers and probes is provided in Table 1.

\section{Compartmentalization of utero-placental RLN-system mRNA expression levels}

Formalin-fixed paraffin-embedded UtPI units from postimplantation $(n=3)$, mid-gestation $(n=3)$ and prepartum luteolysis $(n=3)$ groups were cut with a microtome (two sections per sample, $5 \mu \mathrm{m}$ each) and mounted on Arcturus PEN Membrane Glass slides (Applied Biosystems) previously activated for $30 \mathrm{~min}$ under UV light. Subsequently, sections were air-dried overnight at $37^{\circ} \mathrm{C}$ and on the following day, they were deparaffinized in xylene, rehydrated in a graded, decreasing ethanol series, stained with hematoxylin to enable further morphological identification of histological tissue 
Table 1 List of primers and TaqMan probes used for semi-quantitative RT-PCR and for CRNA probe synthesis for in situ hybridization.

\begin{tabular}{|c|c|c|c|}
\hline Primer & Accession number & Primer sequence & Product length $(b p)$ \\
\hline \multicolumn{4}{|c|}{ Primers and TaqMan probes used for semi-quantitative RT-PCR } \\
\hline \multirow[t]{3}{*}{ GAPDH } & AB028142 & Forward: 5'-GCT GCC AAA TAT GAC GAC ATC A-3' & 75 \\
\hline & & Reverse: 5'-GTA GCC CAG GAT GCC TTT GAG-3' & \\
\hline & & TaqMan Probe: 5'-TCC CTC CGA TGC CTG CTT CAC TAC CTT-3' & \\
\hline \multirow[t]{3}{*}{ RLN } & NM_001003132.1 & Forward: 5'-TGC TAG GTG TCT GGC TGC TAC TAA-3' & 94 \\
\hline & & Reverse: 5'-CGG ACA TAA TCA CGA CCA CAT G-3' & \\
\hline & & TaqMan Probe: 5'-ACT TCC CAG AGA GAT CCC AGC CAC G-3' & \\
\hline \multirow[t]{3}{*}{ RXFP1 } & KY980750 & Forward: 5'-GGC ACC AAT GGA GTG TGT TTC-3' & 102 \\
\hline & & Reverse: 5'-TGC CGC CAA GTT AAC ACC AA-3' & \\
\hline & & TaqMan Probe: 5'-TAC TGG AGC CCA GAT TTA TTC GGT GGC-3' & \\
\hline \multirow[t]{3}{*}{ RXFP2 } & NM_001005870.1 & Forward: 5'-CCC TGT GGG AAT CTT ACC AAG T-3' & 98 \\
\hline & & Reverse: 5'-GTG TCA CCA CAG TTG TCC TCA TC-3' & \\
\hline & & TaqMan Probe: 5'-TTA CCC CGT GCT TTT CAC TGT GAT GGC-3' & \\
\hline \multicolumn{4}{|c|}{ Primers used to generate templates for probes used in in situ hybridization } \\
\hline \multirow[t]{2}{*}{$R L N$} & NM_001003132.1 & Forward: 5'-GGT CGT GAT TAT GTC CGC CT-3' & 220 \\
\hline & & Reverse: 5'-АСТ ТСТ ССТ TCC CAG ACC GT-3' & \\
\hline \multirow[t]{2}{*}{ RXFP1 } & KY980750 & Forward: 5'-CTT GGT GTT AAC TTG GCG GC-3' & 241 \\
\hline & & Reverse: 5'-CCC AAG AGG TTA TGG TAC CTG G-3' & \\
\hline \multirow[t]{2}{*}{ RXFP2 } & NM_001005870.1 & Forward: 5'-CTC GTA TGC TCC CCA TGT CC-3' & 218 \\
\hline & & Reverse: 5'-GGC AGT CTG CAC AAC AAA GG-3' & \\
\hline
\end{tabular}

compartments (i.e., placenta, endometrium and myometrium), and dried overnight at room temperature. Afterwards, using sterile scalpel blades, each tissue compartment was carefully dissected under a stereomicroscope at 50× magnification and transferred immediately into sterile centrifuge tubes. In the next step, total RNA was isolated using the RNeasy FFPE kit (Qiagen) following the manufacturer's protocol. RNA concentrations were measured with a NanoDrop 2000C spectrophotometer (Thermo Fisher Scientific AG) and covered a range from 22.1 to $207.8 \mathrm{ng} / \mu \mathrm{L}$. To eliminate genomic DNA contamination, DNase treatment was done using RQ1 RNase-free DNase (Promega). Subsequently, due to the limited amounts of RNA, following RT-reaction with the High-Capacity cDNA Reverse Transcription Kit (Prod. No. 4368814, Applied Biosystems), cDNA pre-amplification was performed using the TaqMan PreAmp Master Mix Kit (Prod. No. 4384267, Applied Biosystems) according to the supplier's protocol. Briefly, the final reaction mixture consisted of combined primers and probes for each target gene, TaqMan PreAmp Master Mix and $12.5 \mu \mathrm{L}$ of cDNA that corresponded to $10 \mathrm{ng}$ of RNA. Pre-amplification was run in an Eppendorf Mastercycler (Vaudaux-Eppendorf AG, Basel, Switzerland) under the following conditions: enzyme activation at $95^{\circ} \mathrm{C}$ for $10 \mathrm{~min}, 14$ cycles, then $15 \mathrm{~s}$ at $95^{\circ} \mathrm{C}$ and $4 \mathrm{~min}$ at $60^{\circ} \mathrm{C}$. After reaction, samples were diluted in the ratio of 1:20 to a final volume of $1 \mathrm{~mL}$ and subsequently used for semi-quantitative real-time PCR reactions as described above.

\section{Immunohistochemistry}

Since canine-specific and/or cross-reacting antibodies were not available commercially, canine-specific guinea pig polyclonal anti-RXFP1 and RXFP2, custom-made antisera were generated (Eurogentec, Seraing, Belgium) using the following peptide sequences: RXFP1: C+AELDLGSNKIENLPP-NH2, amino acid 217-231 and C+ATEIRNQVKKEMILA-NH2, amino acid 532-546 of canine RXFP1 sequence with GenBank accession number KY980750; RXFP2: C+QTSEVRNPIGREVAV-NH2, amino acid 605-619 and C+LLHKHRRKSIFKTKK-NH2, amino acid 688-702 of canine RXFP2 sequence with GenBank accession number NM_001005870.1. The anti-RLN, canine-specific polyclonal affinity purified anti-RLN custommade antibody was generated in guinea pigs (Eurogentec) and targeted against the IPATDDKKLKAC-NH2 peptide sequence, amino acid 23-34 of the canine RLN sequence with GenBank accession number NM_001003132.1. To mimic the uncharged peptide bond in the protein, a NH2-terminus was added at the C-end of the peptide. Additionally, if needed, a cysteine $(\mathrm{C}+)$ amino acid was added at the $\mathrm{N}$ - or C-terminal position of the peptide to target the coupling site at the carrier protein (Eurogentec).

Immunohistochemical (IHC) staining was done using our previously described immunoperoxidase method (Kowalewski et al. 2006a,b). In brief, formalin-fixed paraffinembedded UtPI compartments were cut on a microtome (2-3 $\mu \mathrm{m}$ thick sections), mounted on SuperFrost microscope slides (Menzel-Glaeser, Braunschweig, Germany) and dried overnight at $37^{\circ} \mathrm{C}$. On the following day, tissue sections were dewaxed in xylene, rehydrated in a graded ethanol series and washed for 5 min under tap water. Subsequently, in order to retrieve antigens, slides were placed in a plastic cuvette containing $10 \mathrm{mM}$ citrate buffer $\mathrm{pH} 6.0$ for $5 \mathrm{~min}$, then heated for $15 \mathrm{~min}$ in a microwave oven set at $600 \mathrm{~W}$. After cooling down for $20 \mathrm{~min}$ at ambient temperature, slides were rinsed under running tap water and placed on a shaker for $30 \mathrm{~min}$ in $0.3 \%$ hydrogen peroxide in methanol, to quench endogenous peroxidase activity. Then, slides were incubated for $5 \mathrm{~min}$ in IHC buffer/0.3\% Triton $\mathrm{X}, \mathrm{pH} 7.2-7.4(0.8 \mathrm{mM}$ $\mathrm{Na}_{2} \mathrm{HPO}_{4}, 1.47 \mathrm{mM} \mathrm{KH}{ }_{2} \mathrm{PO}_{4}, 2.68 \mathrm{mM} \mathrm{KCl}, 137 \mathrm{mM} \mathrm{NaCl}$ ), and subsequently incubated for $20 \mathrm{~min}$ in $10 \%$ goat serum to block nonspecific binding. Finally, sections were incubated 
overnight with primary antibodies at the following dilutions: 1:750 for anti-RLN antibody, 1:1000 for anti-RXFP1 and antiRXFP2 canine-specific antisera. To remove unbound primary antiserum, slides were washed with IHC buffer/0.3\% Triton $X$, and incubated with biotinylated secondary, goat antiguinea pig antibodies (Vector Laboratories, Burlingame, CA, USA) at 1:100 dilution for $30 \mathrm{~min}$ at ambient temperature. After washing with IHC buffer/0.3\% Triton X, in order to enhance signals, slides were incubated with the streptavidinperoxidase Vectastain ABC kit (Vector Laboratories) for $30 \mathrm{~min}$ at room temperature. Using liquid DAB+ substrate kit (Dako), peroxidase activity was detected. Slides were counterstained with hematoxylin, washed under tap water, dehydrated in a graded ethanol series and mounted in Histokit (Assistant, Osterode, Germany). For evaluating specificity of the IHC, the following negative controls were performed: isotype controls consisting of (1) either non-immunized guinea pig IgG instead of the primary antibody (Fig. 5l); (2) pre-immune guinea pig serum (Figs $6 \mathrm{I}$ and $7 \mathrm{I}$ ), both at the same dilution and protein concentration as the primary antiserum; or (3) using primary antibody or antiserum pre-incubated for $2 \mathrm{~h}$ with immunizing peptides used for antibody production (blocking peptides) (Figs 5J, 6J and 7J).

\section{In situ hybridization}

Localization of the RLN-system in canine UtPI compartments was additionally evaluated at the mRNA level by employing a non-radioactive in situ hybridization (ISH) method as described previously (Kowalewski et al. 2006a, 2010). In brief, total RNA from UtPI units was used in RT-PCRs with caninespecific primers for complementary RNA (cRNA) probe synthesis. The sequences of primers and lengths of amplicons are presented in Table 1. PCR products were separated on $2 \%$ agarose gels, stained with ethidium bromide, purified using the QIAquick Gel Extraction Kit II (Qiagen) and ligated into the pGEM-T vector. Afterwards, selected clones were control-digested with $\mathrm{Ncol}$ and Notl restriction enzymes (New England Biolabs, Frankfurt, Germany) and submitted for sequencing (Microsynth). Thereafter, using the restriction enzymes Ncol and Notl, for sense cRNA and antisense cRNA respectively, plasmids were linearized and labeled with the DIG-RNA labeling kit (Roche Diagnostics) according to the manufacturer's protocol. Dot-blot analysis of serial dilutions of DIG-labeled cRNA was performed on positively charged nylon membranes (Roche Diagnostics). To perform non-radioactive $\mathrm{ISH}$, formalin-fixed paraffin-embedded UtPI compartments were cut with a microtome (2-3 $\mu$ m thick sections), mounted on SuperFrost Plus microscope slides (Menzel-Glaeser, Braunschweig, Germany), dewaxed in xylene, rehydrated in a graded ethanol series, digested with proteinase $\mathrm{K}(70 \mu \mathrm{g} /$ $\mathrm{mL}$; Sigma-Aldrich) for permeabilization, post-fixed with $4 \%$ paraformaldehyde and subjected to ISH. The hybridization was performed overnight at $37^{\circ} \mathrm{C}$ in the presence of formamide. Subsequently, to detect DIG-labeled CRNA, slides were incubated with alkaline phosphatase-conjugated sheep antiDIG Fab Fragments (Roche Diagnostics) used at a 1:5000 dilution in $1 \%$ ovine serum following the manufacturer's
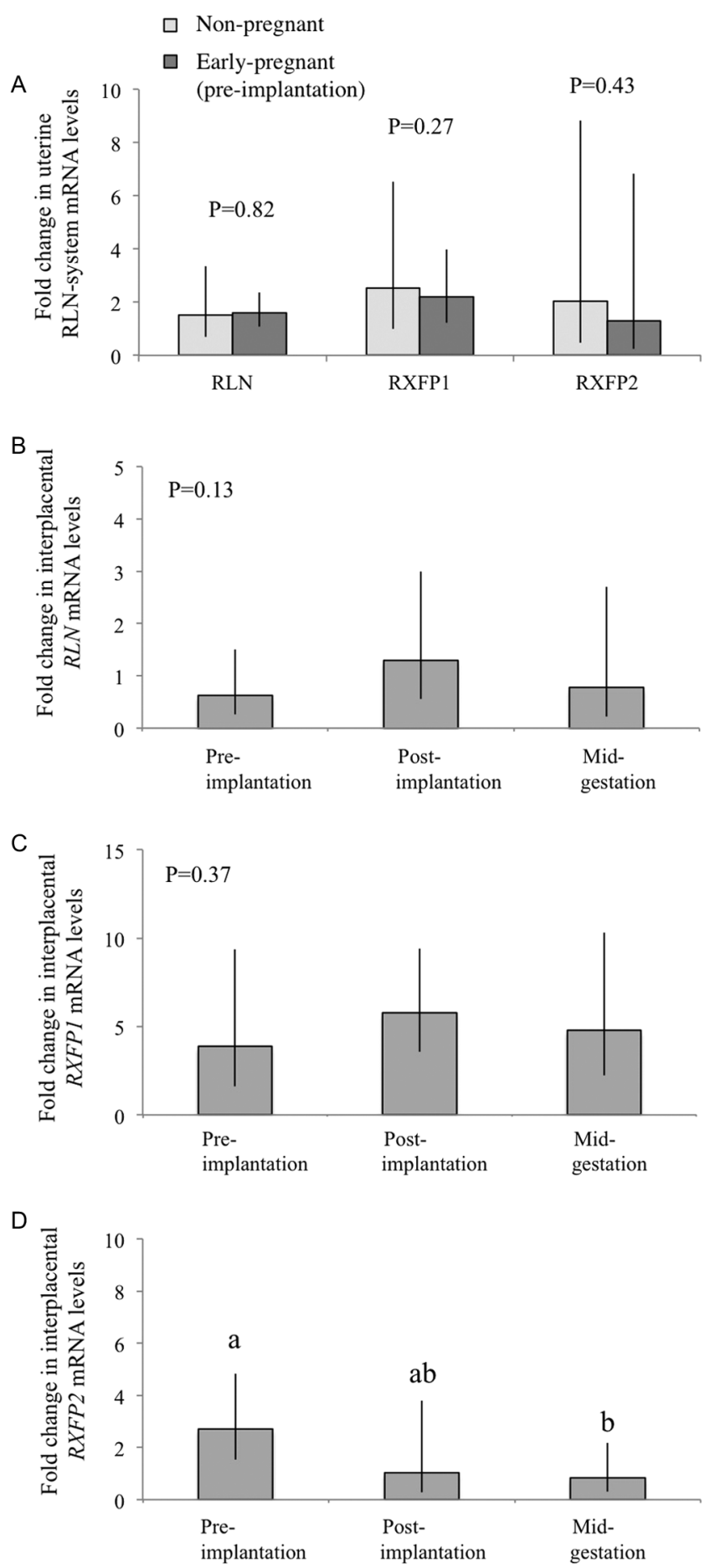

Figure 1 Uterine expression of the $R L N$-system as determined by real-time (TaqMan) PCR. (A) Expression of RLN, RXFP1 and RXFP2 in uteri of non-pregnant and early-pregnant (pre-implantation) bitches. (B) Expression of RLN, (C) RXFP1 and (D) RXFP2 in interplacental sites (IntPl) of the uterus from the pre-implantation period until mid-gestation. Data are presented as $\mathrm{Xg} \pm$ S.D. Bars with different letters differ at $P<0.01$.

instructions. The visualization of signals was done using the substrate 5-bromo-4-chloro-3-indolyl phosphate and nitroblue tetrazolium (BCIP/NBT; Roche Diagnostics). 


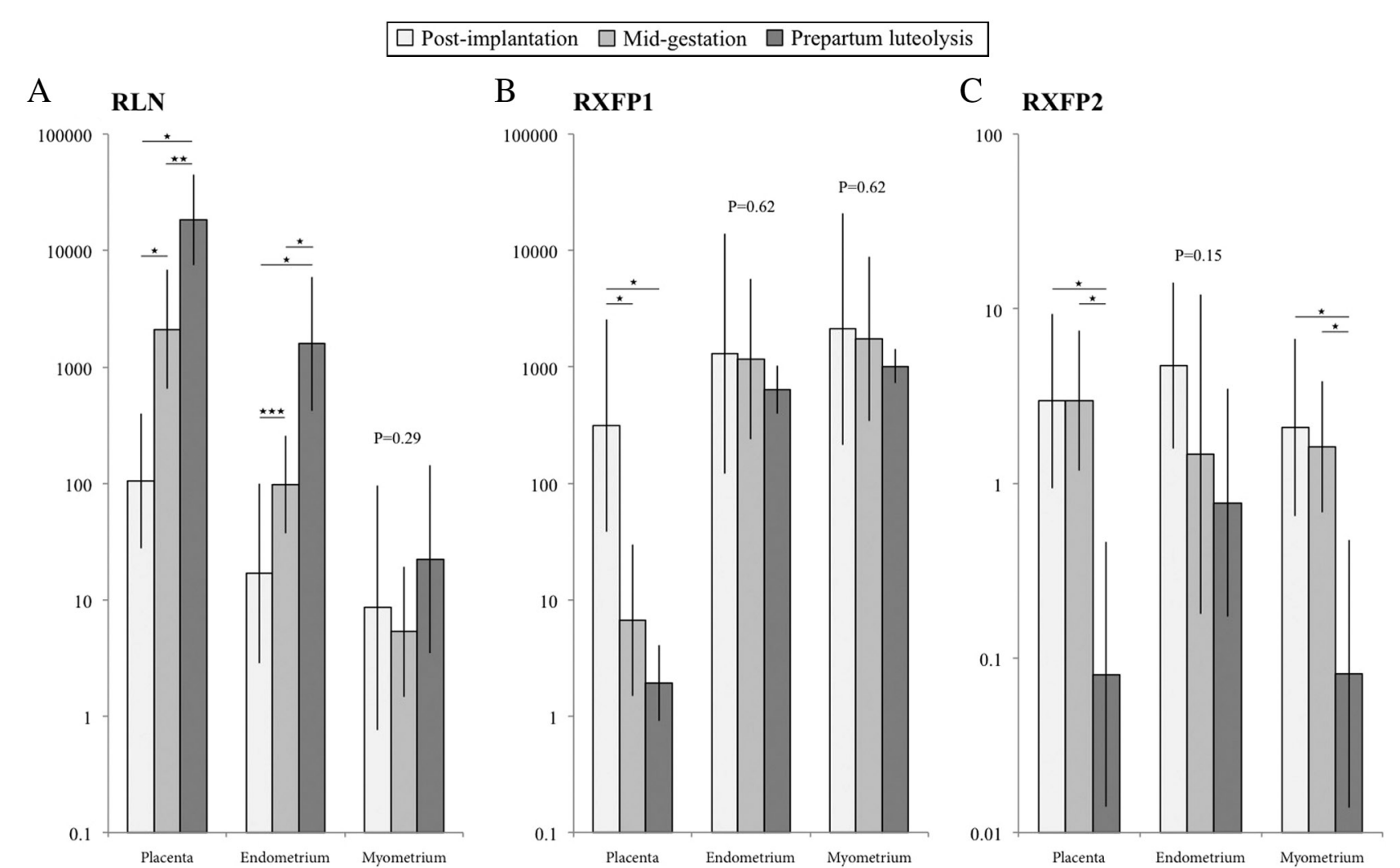

Figure 2 Compartmentalization of RLN (A), RXFP1 (B) and RXFP2 (C) mRNA expression in canine UtPl units during pregnancy. Data are presented with regards to the localization of target gene expression in separate compartments at selected time points during gestation. Real-time (TaqMan) PCR (Xg \pm S.D.) was applied. Results are presented on a logarithmic scale: ${ }^{\star} P<0.001,{ }^{\star} P<0.01,{ }^{\star}{ }^{\star} P<0.05$.

\section{Statistics}

In order to evaluate real-time (TaqMan) PCR data, statistical analysis was performed using the software program GraphPad 3.06 (GraphPad Software). An unpaired, two-tailed Student's $t$-test was performed to compare the levels of RLN and RXFP2 in non-pregnant and pre-implantation uteri. Parametric one-way analysis of variance (ANOVA) was performed followed by a Tukey-Kramer multiple comparisons posttest to determine the effect of time on interplacental RXFP1 and utero-placental RLN-system mRNA expression. For easier presentation and interpretation of data, the latter analyses were performed separately with regards either to the compartment or to the gestation stage. Due to uneven distribution of the data obtained for the uterine RXFP1, interplacental RLN and RXFP2 mRNA expression, the MannWhitney non-parametric test was performed to compare the RXFP1 levels in non- vs early-pregnant uteri and the Kruskal-Wallis test (a non-parametric ANOVA) followed by a Dunn's multiple comparison test (in the event of $P<0.05$ ) was done to determine the effect of time on interplacental RLN and RXFP2 mRNA expression at selected time points of pregnancy. Dunnett's multiple comparison test was used to show RLN-system expression after aglepristone-induced luteolysis. In the latter case, the results show the $n$-fold change in each target gene mRNA compared with its expression at mid-gestation as a non-treated control. The numerical data are presented as geometric means $\mathrm{Xg} \pm$ geometric standard deviation (s.D.).

\section{Results}

\section{Expression of the $R L N$-system in non-pregnant and early-pregnant uteri and uterine expression at interplacental sites}

First the effects of early, pre-attachment embryos on uterine expression of RLN and its two receptors were investigated. The expression of $R L N$ and RXFP1 was detectable in all uterine samples from early-pregnant dogs and their corresponding non-pregnant controls. The expression of RXFP2 mRNA, which varied strongly among individuals, remained below the detection limit in 4 of 8 non-pregnant bitches. As detected by semiquantitative real-time PCR, the levels of all three target genes remained unaffected by the presence of freefloating embryos ( $P>0.05)$ (Fig. 1A).

In the next step, IntPI samples from post-implantation and mid-gestation stages were included and uterine expression of the $R L N$-system was compared during pre-implantation, post-implantation and mid-gestation stages of pregnancy (Fig. 1B, C and D). Whereas the uterine expression of $R L N$ and its two receptors was 


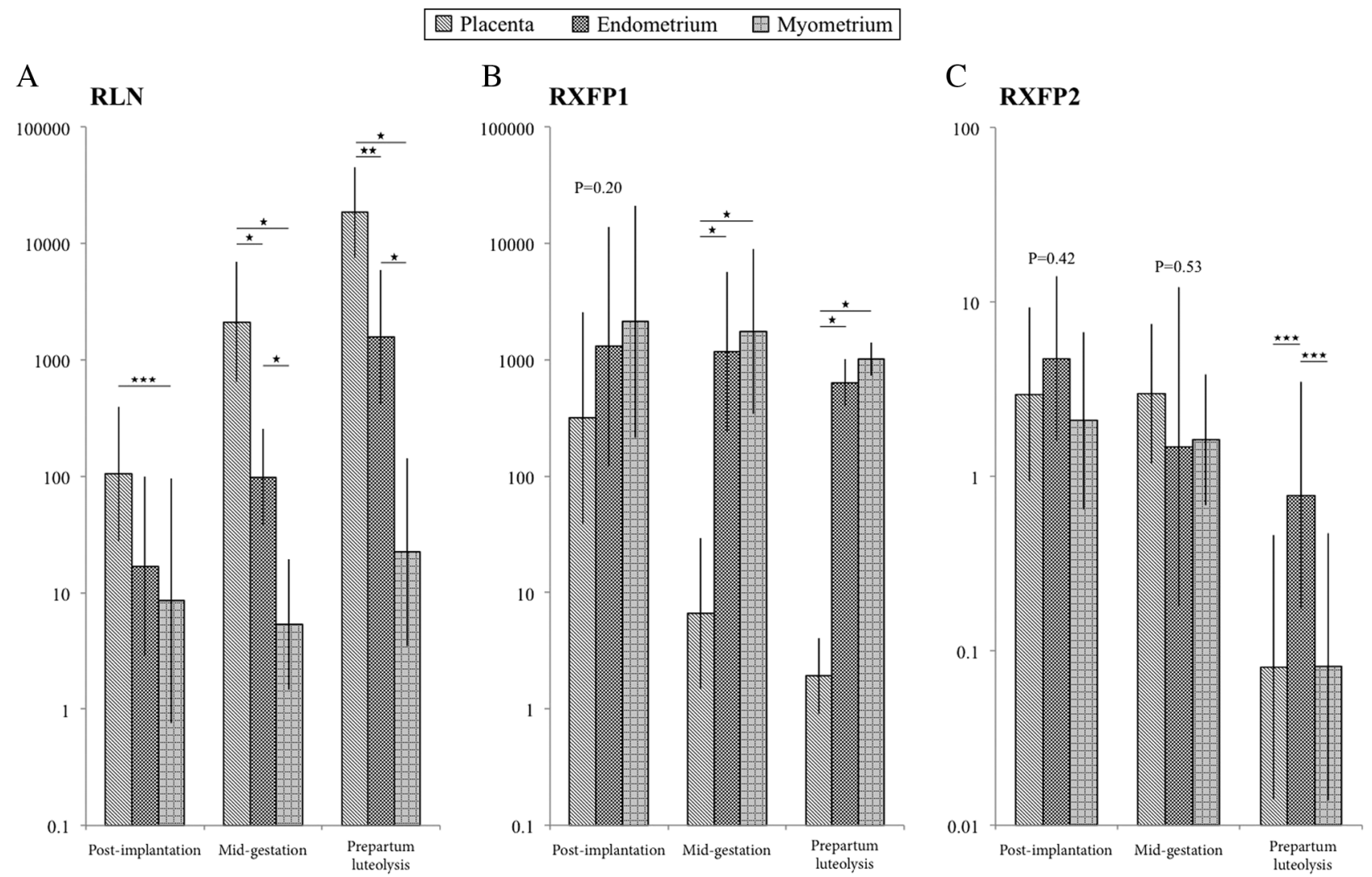

Figure 3 Compartmentalization of RLN (A), RXFP1 (B) and RXFP2 (C) mRNA expression in canine UtPI units during pregnancy. Data are presented with regards to the time point of gestation when the expression of target genes was investigated. Real-time (TaqMan) PCR was applied (Xg士s.D.). Data are presented on a logarithmic scale: ${ }^{\star} P<0.001, \star \star P<0.01, \star \star \star P<0.05$.

detectable at all stages examined, no significant changes $(P>0.05)$ were found for RLN and RXFP1 (Fig. 1B and C). The mRNA levels of RXFP2 changed however, in a timedependent manner and decreased gradually from preimplantation toward mid-gestation $(P<0.01)$ (Fig. 1D).

\section{Compartmentalization of utero-placental RLN-system expression at selected time points during pregnancy}

As indicated in 'Materials and methods' section, data regarding the compartmentalization of utero-placental RLN-system expression throughout pregnancy are presented with reference either to separate compartments (Fig. 2) or particular gestation stage (Fig. 3).

All three members of the RLN-system were expressed in placenta and myometrium during selected stages of gestation (i.e., post-implantation, mid-gestation and prepartum luteolysis). Regarding endometrium, RXFP2 was only undetectable in one animal from the postimplantation group, possibly relating to the low mRNA levels obtained from the dissected compartment in that animal. RLN and RXFP1 were detected in all endometrial samples examined.

Within the compartments, placental RLN expression was time-dependent; it increased significantly at mid-gestation compared with post-implantation $(P<0.001)$, and was further elevated at prepartum luteolysis $(P<0.001$ and $P<0.01$, compared with post-implantation and mid-gestation respectively) (Fig. 2A). A similar expression pattern was observed for endometrial RLN expression, with a gradual but significant increase from post-implantation to midgestation $(P<0.05)$, and the highest mRNA levels were detected at prepartum luteolysis $(P<0.001$ when compared with both post-implantation and mid-gestation) (Fig. 2A). Myometrial RLN levels remained unaffected by the stage of pregnancy $(P=0.29)$ (Fig. 2A).

The placental expression of RXFP1 revealed the highest abundance of transcripts during the postimplantation period of pregnancy, followed by a significant decrease at mid-gestation $(P<0.001)$, and no further changes were observed at prepartum luteolysis $(P>0.05)$ (Fig. 2B). The endometrial and myometrial expression of RXFP1 did not change significantly over time $(P=0.62)$ (Fig. 2B). Expression patterns of RXFP2 were similar showing time-related changes within placental and myometrial compartments. Thus, it stayed elevated during post-implantation and mid-gestation stages, but decreased significantly at 

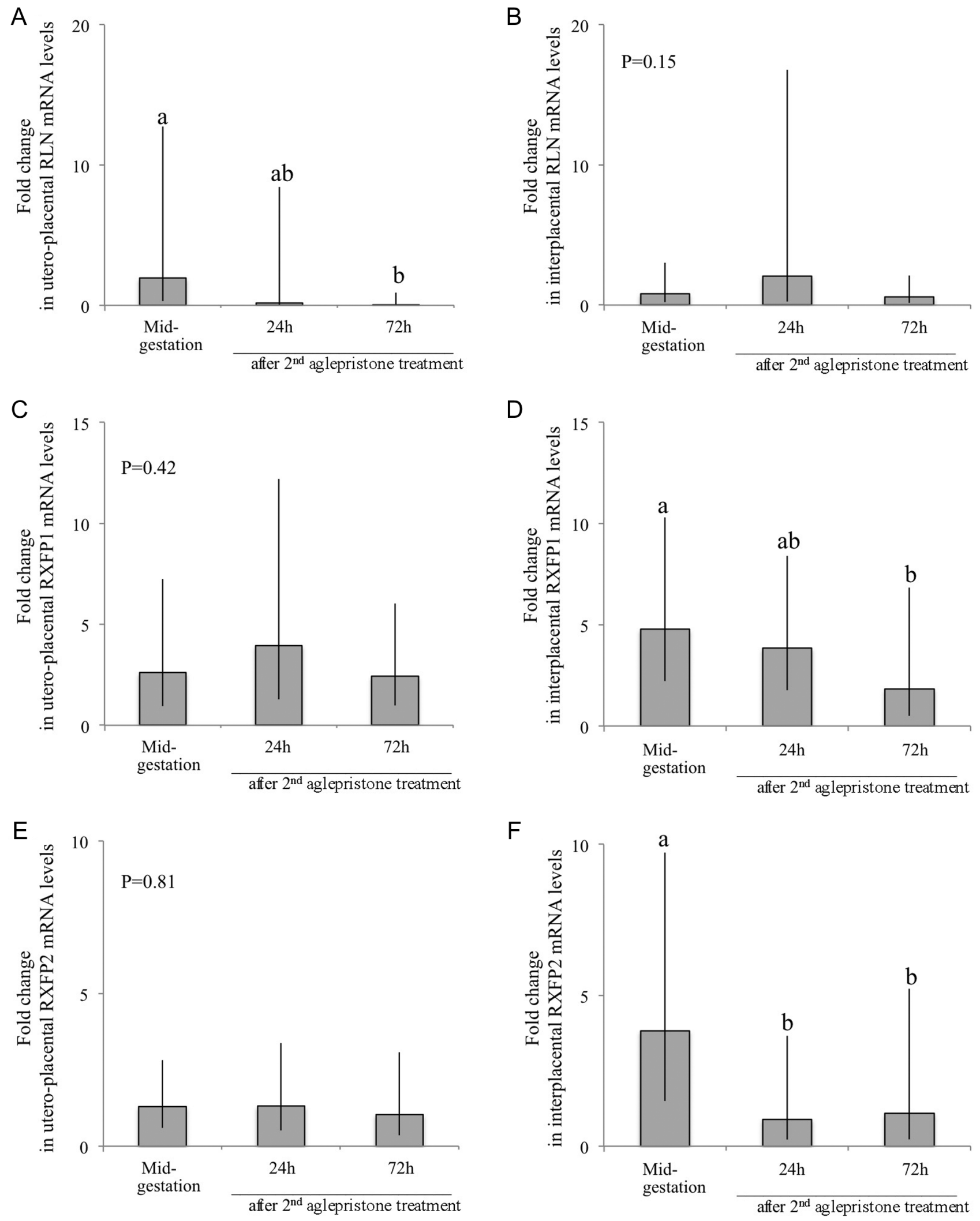

Figure 4 Antigestagen (aglepristone) effects on utero-placental (UtPI) (A, C, E) and interplacental (IntPI) (B, D, F) expression of the RLN-system (RLN, RXFP1 and RXFP2), as determined by real-time (TaqMan) PCR. Data are presented as $\mathrm{Xg} \pm$ S.D. Bars with different letters differ at $P<0.01$ (A) or $P<0.05(\mathrm{D}, \mathrm{F})$, compared to the mid-gestation group as a non-treated control. 
RLN
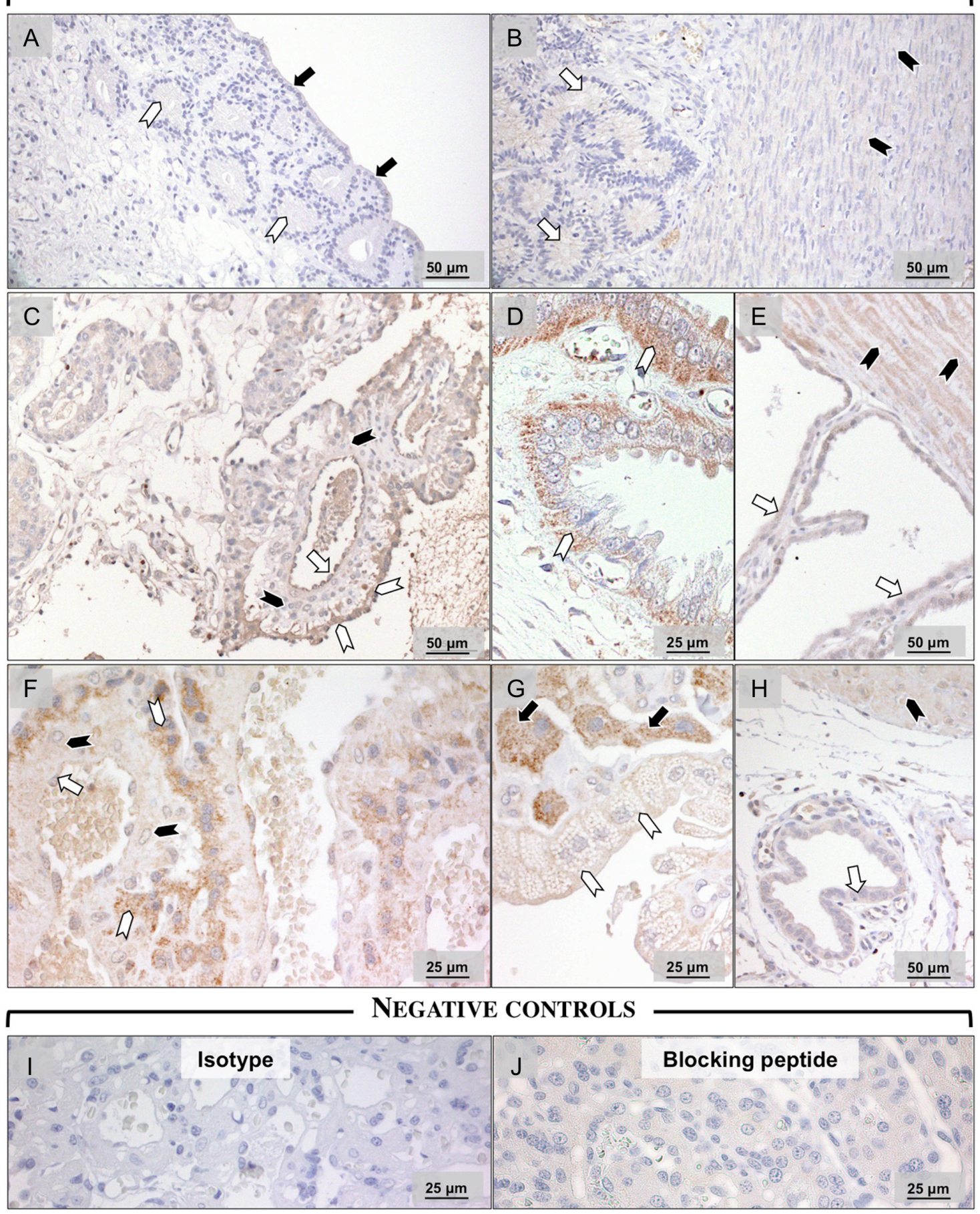

Figure 5 Localization of RLN in canine uterus during pre-implantation (A, B), and in utero-placental compartments during mid-gestation (C, D, E) and at prepartum luteolysis ( $F, G, H)$ by immunohistochemistry using canine-specific antibody; representative pictures are shown. (A, B) During pre-implantation, only weak or no uterine signals are observed: solid arrows in $(A)=$ surface (luminal) epithelium, open arrowheads in $(A)=$ superficial uterine glands, open arrows in $(B)=$ deep uterine glands, solid arrowheads in $(B)=$ myometrium. Post-implantation and at prepartum luteolysis placental RLN is mostly localized in cytotrophoblast cells (open arrowheads in C and F); only weak or no signals are detected in syncytiotrophoblast cells (solid arrowheads in C and F) and in endothelium of maternal blood vessels (open arrows in C and F). Signals appear to be stronger in the placenta during prepartum luteolysis. (D, G) Endometrial signals of RLN are localized in the superficial uterine glands (the so-called glandular chambers) (open arrowheads in D and G); strong signals are observed also in invading trophoblast (solid arrows on G). (E, H) RLN signals in deep uterine glands (open arrows in E and $\mathrm{H}$ ) and myocytes (solid arrowheads in E and H). (I, J) Negative controls: the specificity of staining was controlled by incubation with non-immune guinea pig lgG instead of primary antibody (isotype control, I) or with primary antibody pre-incubated for $2 \mathrm{~h}$ with peptide used for antibody production (blocking peptide, J). 



Figure 6 Localization of RXFP1 in canine uterus during pre-implantation (A, B), and in utero-placental compartments during mid-gestation (C, $\mathrm{D}, \mathrm{E})$ and at prepartum luteolysis $(\mathrm{F}, \mathrm{G}, \mathrm{H})$ by immunohistochemistry using canine-specific antibodies; representative pictures are shown. (A, B) During pre-implantation, RXFP1 protein is strongly present in uterine epithelium (solid arrows in A) and superficial glands (open arrowheads in A), as well as in the deep uterine glands (open arrows in B) and myocytes (solid arrowheads in B). (C, F) Strong placental signals of RXFP1 are localized in maternal endothelial cells (open arrows in C and F). In particular, at prepartum luteolysis signals are also localized in cytotrophoblast cells (open arrowheads in F); weaker signals are localized in syncytiotrophoblast (solid arrowheads in C, F). (D, G) Endometrial signals of RXFP1 in the superficial uterine glands (the so-called glandular chambers) (open arrowheads in D and G); strong signals are also observed in invading trophoblast (solid arrows in G). (E, H) RXFP1 signals are localized in deep uterine glands (open arrows in E and H) and myocytes (solid arrowheads in E and H). (I, J) Negative controls: the specificity of staining was controlled by incubation with pre-immune guinea pig serum instead of primary antibody (isotype control, I) or with primary antiserum pre-incubated for $2 \mathrm{~h}$ with peptides used for antibody production (blocking peptides, J). 


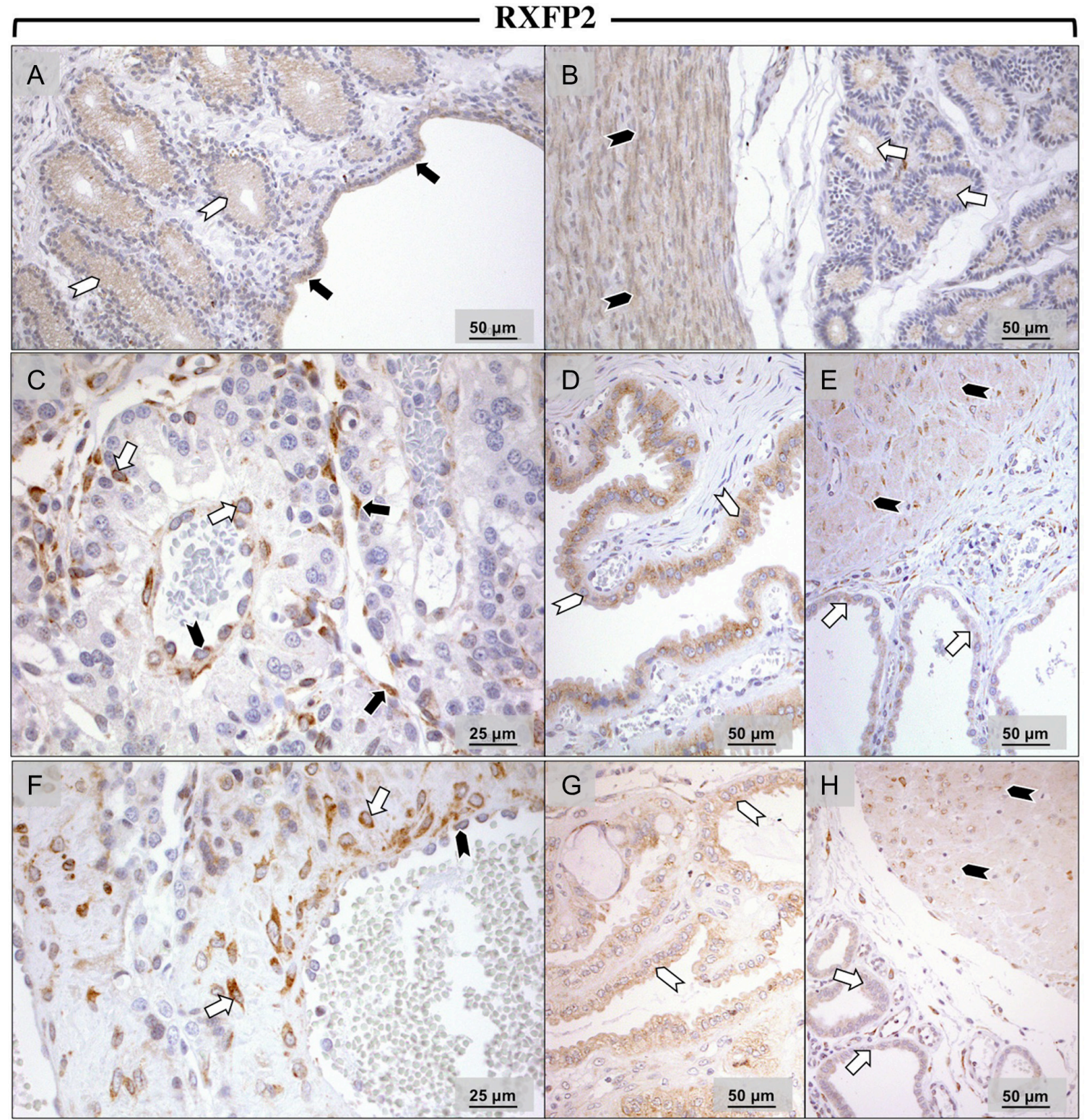

NEGATIVE CONTROLS

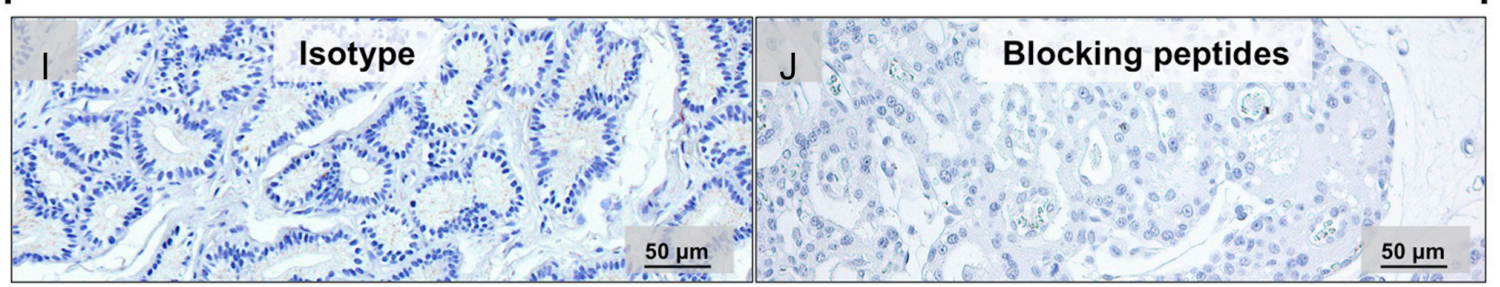

Figure 7 Localization of RXFP2 in canine uterus during pre-implantation (A, B), and in utero-placental compartments during mid-gestation (C, $D, E)$ and prepartum luteolysis $(F, G, H)$ by immunohistochemistry using canine-specific antibodies; representative pictures are shown. (A, B) During pre-implantation, RXFP2 is predominantly present in uterine surface (luminal) epithelium (solid arrows in A) and superficial glands (open arrowheads in A), as well as in the deep uterine glands (open arrows in B) and myocytes (solid arrowheads in B). (C, F) Placental signals for RXFP2 are predominantly localized in maternal stroma-derived decidual cells (open arrows in C and F), occasional staining can also be observed in fetal fibroblasts (solid arrows in C); weaker signals are also localized in endothelium of maternal blood vessels (solid arrowheads in $\mathrm{C}$ and F). (D, G) Endometrial signals of RXFP2 in the superficial uterine glands (the so-called glandular chambers) (open arrowheads in D and $\mathrm{G})$. (E, H) RXFP2 signals in deep uterine glands (open arrows in E and H) and myocytes (solid arrowheads in E and H). (I, J) Negative controls: the specificity of staining was controlled by incubation with pre-immune guinea pig serum used instead of primary antibody (isotype control, I) or with primary antiserum pre-incubated for $2 \mathrm{~h}$ with peptides used for antibody production (blocking peptides, J). 

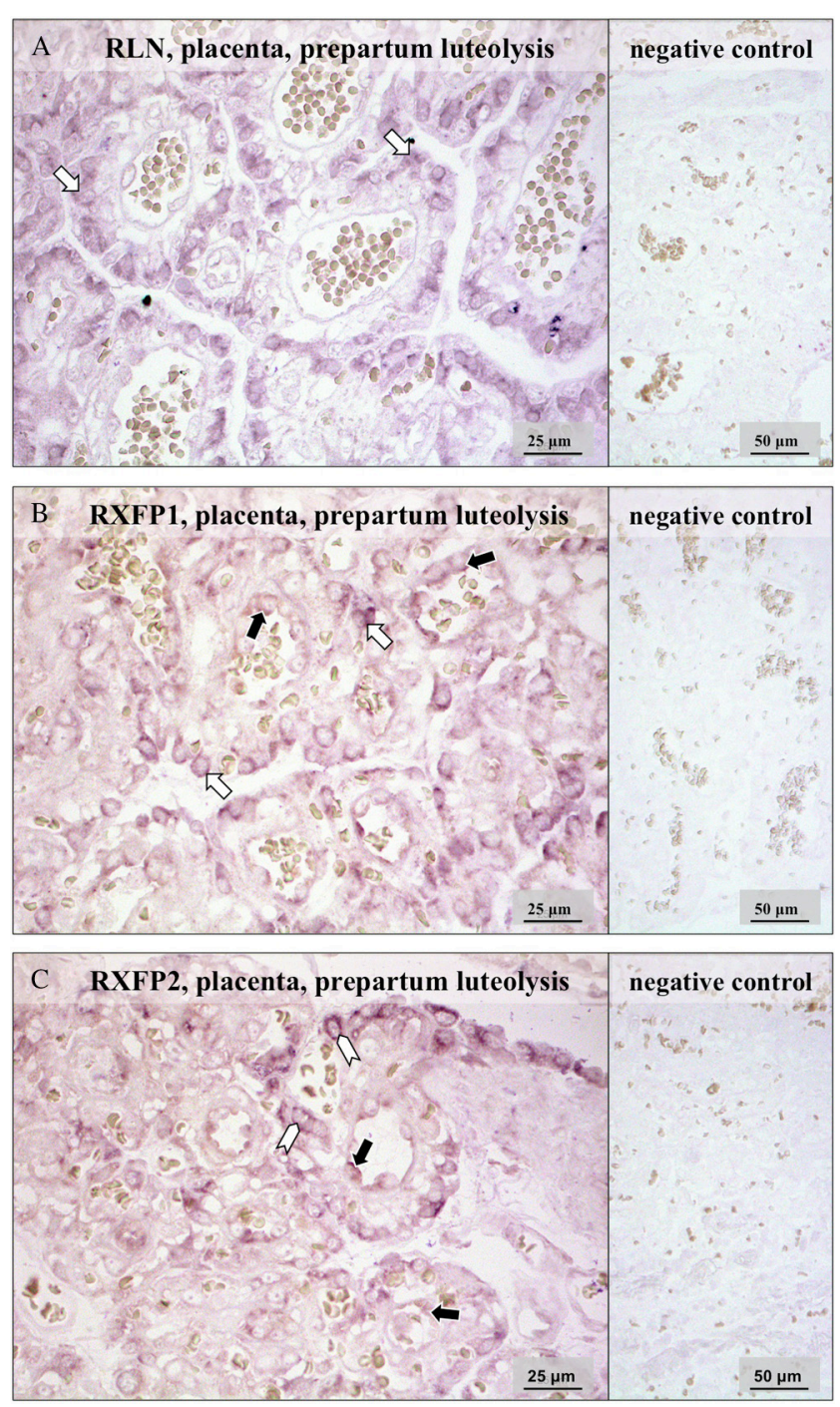

Figure 8 Localization of $R L N(\mathrm{~A}), \operatorname{RXFP1}(\mathrm{B})$ and $R X F P 2$ (C) mRNA in the canine placenta during prepartum luteolysis by in situ hybridization (ISH). RLN and RXFP1 signals are localized predominantly in the cytotrophoblast (open arrows in A and B); strong signals for RXFP2 mRNA are localized in the maternal decidual cells (open arrowheads in C); mRNA of both receptors is found in the endothelial cells (solid arrows in B and C). There is no background staining in the negative control (sense probe).

prepartum luteolysis $(P<0.001$, compared with both post-implantation and mid-gestation). Its endometrial expression did not change significantly over time $(P=0.15)$ (Fig. 2C).

Regarding gestational stages (i.e., post-implantation, mid-gestation and prepartum luteolysis) (Fig. 3), RLN was consistently highest in the placenta, followed by endometrium and myometrium (statistical details are presented in Fig. 3A). Whereas post-implantation placental expression of RXFP1 did not vary strongly $(P=0.20)$ between compartments (i.e., placenta, endometrium and myometrium), at mid-gestation and prepartum luteolysis its placental expression was significantly lower compared with endometrium and myometrium $(P<0.001)$. The myometrial and endometrial expression of RXFP1 did not differ significantly $(P>0.05)$ at both stages of pregnancy.

The expression of RXFP2, which did not differ significantly between the compartments during postimplantation and mid-gestation stages $(P=0.42$ and $P=0.53$ respectively), was significantly more highly expressed in endometrium than in placenta and myometrium during prepartum luteolysis $(P<0.05)$.

\section{The effects of antigestagen treatment on expression of the RLN-system in canine utero-placental units and interplacental sites}

Antigestagen treatment was applied to mid-pregnant bitches and the effects on RLN, RXFP1 and RXFP2 expression were investigated in UtPI and IntPI samples (Fig. 4). Corresponding samples from mid-pregnant bitches were used as non-treated controls in Dunnett's multiple comparisons test. The expression of RLN decreased significantly in UtPI $(P<0.01) 72 \mathrm{~h}$ after the second treatment (Fig. 4A). However, its expression in IntPI did not change significantly ( $P=0.15)$ (Fig. 4B). The opposite effect was observed for both RLN receptors: whereas their expression at IntPl was significantly decreased in aglepristone-treated dogs, showing significant effects either at $72 \mathrm{~h}$ (for RXFP1) or at $72 \mathrm{~h}$ and $24 \mathrm{~h}$ (for RXFP2) after the second application $(P<0.05)$ (Fig. 4D and F), in UtPl expression levels did not change significantly $(P=0.42$ and $P=0.81$ for $R X F P 1$ and $R X F P 2$ respectively) (Fig. $4 \mathrm{C}$ and $\mathrm{E}$ ).

\section{Localization of RLN, RXFP1 and RXFP2 in utero-placental units throughout gestation}

At the protein level, localization of the utero-placental expression of the RLN-system was determined by IHC using the canine-specific custom-made antibodies produced against each target. No or only very weak signals (mostly in deep uterine glands and myometrium) were detected for RLN expression prior to implantation (Fig. 5A and B). However, following implantation RLN expression was clearly detectable with staining intensity appearing stronger during the later stages of pregnancy, i.e., at mid-gestation and prepartum luteolysis (Fig. 5C, D, E, F, G and H). Placental RLN was localized mainly in fetal cytotrophoblast cells; only weak signals were detected in syncytiotrophoblast and endothelium of maternal blood vessels (Fig. 5C and F). Additionally, RLN appeared intensively in invading trophoblast cells (Fig. 5G). The uterine RLN distribution consisted of signals located in epithelial compartments of superficial glands (the so-called glandular chambers), deep glands and in myometrium (Fig. 5D, E and H). 

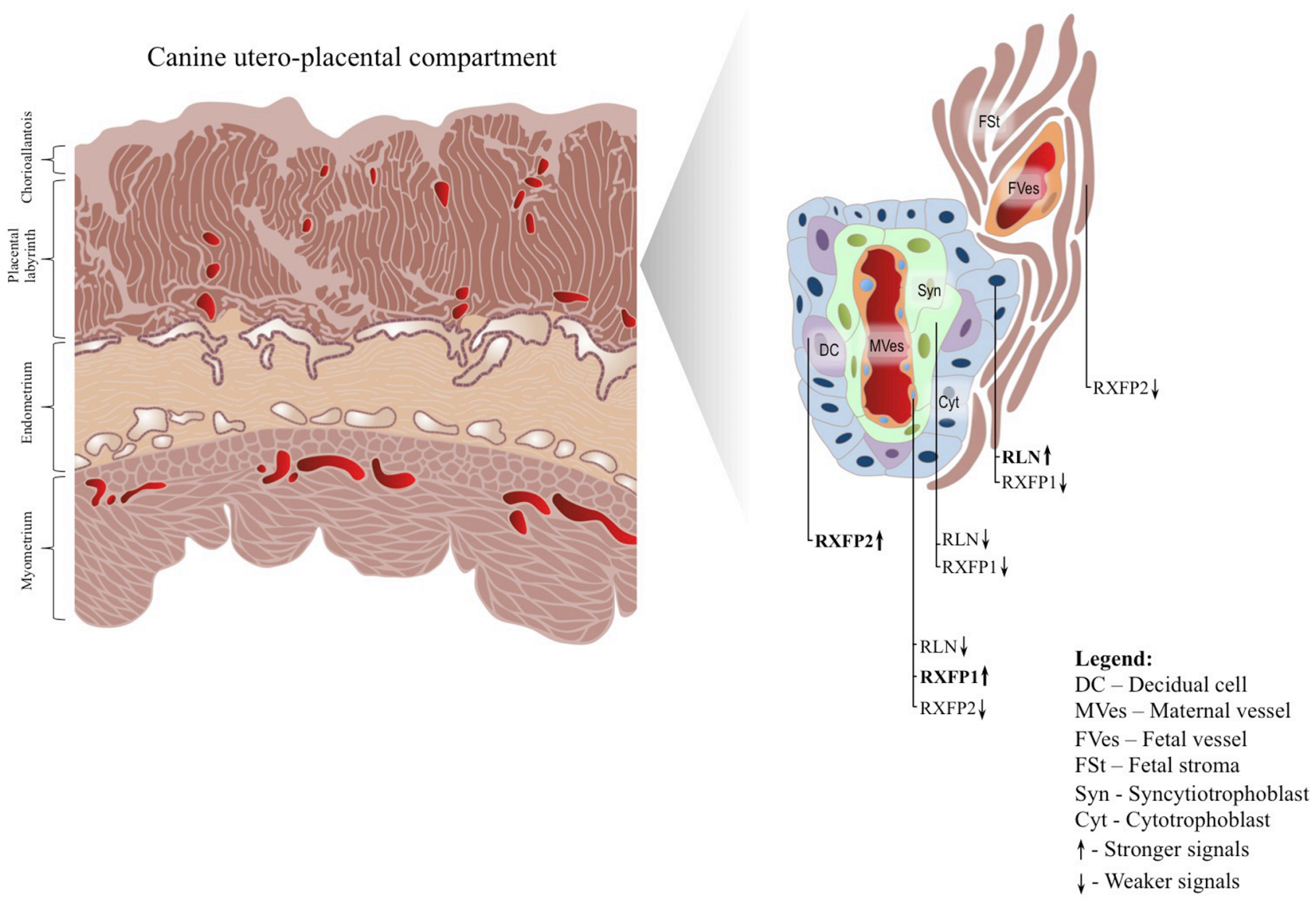

Figure 9 Schematic representation of placental RLN-system distribution within canine utero-placental compartments (placenta endotheliochorialis) as determined by immunohistochemistry and in situ hybridization. From post-implantation to prepartum luteolysis RLN protein expression is localized mainly in cytotrophoblast cells, while weaker signals are found in syncytiotrophoblast and maternal endothelial cells. RXFP1 is localized predominantly in endothelial cells of maternal blood vessels. Additionally, weaker RXFP1 signals are observed in fetal trophoblast cells (in particular in cytotrophoblast cells at prepartum luteolysis). RXFP2 is strongly represented in maternal stroma-derived decidual cells and occasionally in some fetal fibroblasts. Also, maternal endothelial cells stain positively for RXFP2 however not as strongly as for RXFP1.

In contrast to RLN, both RXFP1 and RXFP2 proteins were clearly detectable at earlier stages of pregnancy, namely in the pre-implantation uterus (Figs 6A, B and $7 \mathrm{~A}, \mathrm{~B})$. Their expression was particularly strong in epithelial cellular constituents of the endometrial surface (luminal) epithelium and superficial and deep glands. Myometrial signals were clearly distinguishable throughout gestation, while lesser signals were observed in stroma. These similar uterine distribution patterns of both receptors were maintained following implantation until prepartum luteolysis (Figs 6 and 7D, $E, G, H)$. However, their localization patterns differed in the placenta, where RXFP1 was found mostly in the endothelial cells throughout placentation (Fig. 6C and F), with some weaker signals located in fetal trophoblast cells (predominantly in cytotrophoblast) (Fig. 6C and F), whereas placental RXFP2 expression was predominantly localized in maternal stroma-derived decidual cells (Fig. 7C and F). Some fetal stromal cells occasionally stained for RXFP2. Further, staining for RXFP2 was also observed in endothelial cells of mid-pregnant placenta, with signals however, appearing less pronounced than those of RXFP1.

At the mRNA level, as detected by ISH, the localization patterns of RLN, RXFP1 and RXFP2 were similar to those signals observed for their respective protein targets (Fig. 8). A schematic representation of the placental distribution of RLN-system signals is shown in Fig. 9.

\section{Discussion}

RLN is an important hormone of pregnancy and the only diagnostically applicable marker of pregnancy in dogs. Thus, it is surprising that its expression, distribution and possible local functionality within the uterus and placenta in the dog remain largely unknown.

Therefore, our goal was to investigate the spatiotemporal expression and localization of RLN and its two receptors, RXFP1 and RXFP2 (RLN-system), during 
gestation and at normal (i.e. spontaneous, prepartum) and antigestagen-induced luteolysis.

Here, for the first time we show the expression of the $\mathrm{RLN}$-system in the canine pregnant uterus throughout pregnancy, beginning with its early pre-implantation stage. Whereas the local uterine expression of RLN appeared to be weak at the protein level, the expression of its receptors was clearly detectable, especially at the protein level, and was predominantly found in the endometrial epithelial components. This implies possible autocrine/paracrine effects of RLN in the canine uterus at early diestrus. At this stage however, these effects do not appear be pregnancy-related because the presence of free-floating embryos did not affect uterine expression of the RLN-system. Shortly after implantation, RLN becomes detectable in the maternal circulation, its secretion increases with the progression of placental development and it remains high until parturition (Tsutsui \& Stewart 1991). The placentationassociated increase in RLN coincides with our detection of RLN in the UtPI units, predominantly in the placenta, as also described elsewhere (Klonisch et al. 1999). However, as revealed in our study by applying caninespecific anti-RLN antibody, cytotrophoblast, and not syncytiotrophoblast, appears to be the main provider of circulating RLN. Moreover, in addition to a previous report (Klonisch et al. 1999), although RLN expression remains consistently highest within the placenta, its endometrial expression at placentation sites also increases continuously throughout pregnancy. This has been clearly shown by the compartmentalization study presented herein. Its expression does not change, although at IntPI sites, i.e., at uterine sites not connected with the placenta, indicating the role of local interactions in regulatory mechanisms affecting RLN expression and possibly function at the feto-maternal interface. Localization of RLN was mostly associated with glandular epithelium, suggesting its involvement in endometrial secretory activity. The uterine expression of both receptors remained similar at IntPI and UtPI sites.

The local effects of RLN are mediated via its specific receptors. In addition to their strong representation in endometrial epithelial cells, both receptors, but predominantly RXFP1, were found in endothelial cells of maternal blood vessels. This in particular concerns their placental expression. RLN was reported to exert vasodilatatory effects, both in vivo and in vitro, in systemic arterioles, capillaries and venules, including those present in the reproductive organs (Vasilenko et al. 1986, Lee et al. 1992, Longo et al. 2003) and to contribute to endometrial angiogenesis in vivo and in vitro (Pillai et al. 1999, Unemori et al. 1999), e.g., by stimulating the expression of vascular endothelial growth factor (VEGF) (Unemori et al. 1999). It thus appears plausible that RLN also participates in placental vascular system development and activity in the dog, by differential utilization of its receptors. Accordingly, apart from the similar uterine localization of both receptors, their cellular localization within the canine placenta diverged strongly. Thus, whereas RXFP1 was mainly co-localized with placental RLN in cytotrophoblast cells, RXFP2 was predominantly targeted to maternal decidual cells. This may be important, as being derived from uterine stromal cells in the process referred to as decidualization (Kautz et al. 2015, Graubner et al. 2017), these are the only cells in the canine placenta bearing the nuclear $\mathrm{P} 4$ receptor (PGR). The RXFP2-mediated effects of RLN in regulating decidual cell function should therefore be considered. It is noteworthy that, apart from being one of the two RLN receptors, RXFP2 also acts as the main receptor for insulin-like 3 protein (INSL3) (Bathgate et al. 2006c). Whereas RLN binds to both receptors, INSL3 has only a low affinity for RXFP1 (Scott et al. 2012). As for female reproductive physiology, e.g., in cattle, the expression of INSL3 and its receptor RXFP2 has been implicated in ovarian follicular and luteal development (Satchell et al. 2013). It thus seems that RXFP2 could play a role in a multifactorial regulation of utero-placental function, with particular regard to placental decidual cells. This may apply also to other species, e.g., humans, in which the involvement of RXFP2 in maternal decidual cell biology remains unclear (Hombach-Klonisch et al. 2001). And indeed, RLN induces decidualization of human endometrial stromal cells in vivo by stimulating intracellular cAMP production (Telgmann et al. 1997, Telgmann \& Gellersen 1998). Similarly, cAMP-mediated decidualization effects have been recently shown in our studies with canine uterine stromal cells in vitro (Kautz et al. 2015, Graubner et al. 2017).

Interestingly, concomitantly with increasing RLN levels, the local placental expression of both receptors decreases toward normal prepartum luteolysis. This suggests a functional shift from local to systemic endocrine effects of RLN during preparation for labor. On the other hand, RLN may exert regulatory feedback effects on the expression of its receptors, thereby coordinating its own local bioavailability.

Regarding the myometrium, RLN and RXFP 1 levels did not change over time however RXFP2 levels decreased at prepartum luteolysis. In particular, the consistently strong presence of myometrial RXFP1 implies RLNmediated involvement in growth and development of the uterus and, possibly, in sustaining uterine quiescence during pregnancy, as shown previously in vitro in pigs and rodents (Griss et al. 1967, MacLennan et al. 1986). The latter hypothesis needs to be verified for the dog in which possible involvement of RLN in myometrial contractility remains unknown. If they exist in dogs, these effects could be of rather a secondary nature by preventing the uterus from spontaneous contractions, while physiological myometrial contractility still occurs 
when plasma RLN is elevated and RXFP1 is available in the myometrium.

Interfering with P4 function at the level of PGR by administering its antagonist aglepristone initiates the luteolytic cascade in the dog and results in prepartum PGF2 $\alpha$ release (Kowalewski et al. 2010). The latter must originate in fetal trophoblast cells where the enzymatic machinery responsible for prostaglandin synthesis is strongly active (Kowalewski et al. 2010). Contrasting with normal prepartum luteolysis, in this study, after functional withdrawal of $\mathrm{P} 4$, we observed suppression of RLN expression in UtPl but not in IntPI sites, indicating this decrease to be related to placental RLN synthesis. Thus, RLN expression was suppressed $24 \mathrm{~h}$ after the second treatment with aglepristone and was further significantly decreased at $72 \mathrm{~h}$. Both receptors were negatively affected by the treatment at IntPI sites. All antigestagen-mediated effects were associated with strong individual variations in gene expression. Our observations are in agreement with previously reported data showing decreased blood levels of RLN in dogs with aglepristone-induced abortions (Gunzel-Apel et al. 2009). It seemed however, to be an effect of placental disintegration that led to the RLN decrease, rather than a rapid reaction to P4 withdrawal, because no immediate treatment-related changes in RLN secretion patterns were observed in that study. In another study (Schafer-Somi et al. 2007) in dogs treated with aglepristone at Day 30 of pregnancy, RLN levels were not altered during abortion but decreased continuously thereafter. In both of those studies, circulating RLN varied strongly among individuals upon aglepristone treatment. The effects exerted by antigestagen on utero-placental RLN secretion thus seem, at least in part, to be linked to individual responsiveness to the luteolytic insult and the time of pregnancy when the treatment was applied. Progesterone however, does not seem to be directly involved in regulating utero-placental RLN synthesis in the dog. While RLN does not seem to be involved in the initiation of labor, there are several pieces of evidence that it affects the duration of parturition (Nara et al. 1982, Downing \& Sherwood 1985, Burger \& Sherwood 1995). Therefore, the RLN decrease after administering a PGR antagonist at gestational stages when fetal resorption is not possible any more could potentially result in slower passage of pups through the birth canal and an extended total duration of the abortion.

In conclusion, by showing the uterine and placental expression of the RLN-system during gestation, and especially by demonstrating changes occurring during parturition, here new insights into the physiology of canine pregnancy are provided. Custom-made caninespecific antibodies were generated that allowed us to investigate the cellular localization of the RLNsystem within the canine uterus and placenta. In this way, evidence has been provided that within the canine placenta, cytotrophoblast is the main source of circulating RLN (summarized in schematic Fig. 9). Additionally, the basic synthetic capability of canine uterus to produce RLN has been shown. Moreover, by establishing RXFP1 and RXFP2 expression and localization, we can conclude that RLN targets are widespread in canine reproductive tissues and include both fetal and maternal parts of the placenta, as well as endothelium of placental blood vessels and uterus. Acting locally in the uterus and placenta, RLN may act also in an autocrine and paracrine manner. Thus, besides being involved in preparation for parturition, it seems to exert other, e.g., angiogenic and secretory, effects. Furthermore, a new interesting aspect of feto-maternal communication in the dog has been brought to light by revealing the spatial distribution of RLN receptors. This in particular concerns the maternal decidual cell-targeted expression of RXFP2, strongly implying functional roles of RLN during the decidualization process and thereby determining one of our future study directions. From the practical point of view, the opposing patterns of RLN expression during natural and antigestagen-induced luteolysis clearly indicate differences in endocrine and cell-biological mechanisms existing between natural labor and antigen-induced abortion, which may have clinical implications.

\section{Declaration of interest}

The authors declare that there is no conflict of interest. All authors read and approved the final version of the manuscript.

\section{Funding}

This work was supported by The Swiss National Science Foundation (SNSF) research grant number 31003A_160251 to MPK.

\section{Author contribution statement}

$\mathrm{MN}$ was involved in developing the concept of the study, experimental design, generating data, analysis and interpretation of data and writing of the manuscript. A G was involved in knowledge transfer, involvement in the laboratory part of the project and tissue processing. S A, S S A and $\mathrm{F} O \mathrm{O}$ were involved in tissue sampling procedures and knowledge transfer. A B was involved in knowledge transfer, critical discussion of data and editing of the manuscript. M P K designed and supervised the project, was involved in the interpretation of the data, drafting and revising the manuscript. All authors read and approved the final manuscript.

\section{Acknowledgements}

Authors are grateful to Dr Barry Bavister for careful editing of the manuscript. Part of the laboratory work was performed using the logistics at the Center for Clinical Studies, Vetsuisse 
Faculty, University of Zurich. The technical expertise and contributions of Elisabeth Högger are gratefully appreciated.

\section{References}

Anderson MB \& Sherwood OD 1984 Ultrastructural localization of relaxin immunoreactivity in corpora lutea of pregnant rats. Endocrinology 114 1124-1127. (doi:10.1210/endo-114-4-1124)

Anderson MB, Vaupel MR \& Sherwood OD 1984 Pregnant mouse corpora lutea: immunocytochemical localization of relaxin and ultrastructure. Biology of Reproduction 31 391-397. (doi:10.1095/biolreprod31.2.391)

Bathgate RA, Aaron JWH \& Sherwood OD 2006a Physiology and molecular biology of the relaxin peptide family. In Knobil and Neill's Physiology of Reproduction, 3rd edition, vol 1, pp. 679-768. Amsterdam: Elsevier Academic Press

Bathgate RA, Ivell R, Sanborn BM, Sherwood OD \& Summers RJ 2006b International Union of Pharmacology LVII: recommendations for the nomenclature of receptors for relaxin family peptides. Pharmacological Reviews 58 7-31. (doi:10.1124/pr.58.1.9)

Bathgate RA, Lin F, Hanson NF, Otvos L Jr, Guidolin A, Giannakis C, Bastiras S, Layfield SL, Ferraro T, Ma S et al. 2006c Relaxin-3: improved synthesis strategy and demonstration of its high-affinity interaction with the relaxin receptor LGR7 both in vitro and in vivo. Biochemistry 45 1043-1053. (doi:10.1021/bi052233e)

Bathgate RA, Halls ML, van der Westhuizen ET, Callander GE, Kocan M \& Summers RJ 2013 Relaxin family peptides and their receptors. Physiological Reviews 93 405-480. (doi:10.1152/physrev.00001.2012)

Burger LL \& Sherwood OD 1995 Evidence that cellular proliferation contributes to relaxin-induced growth of both the vagina and the cervix in the pregnant rat. Endocrinology 136 4820-4826. (doi:10.1210/ endo.136.11.7588212)

Concannon PW 2011 Reproductive cycles of the domestic bitch. Animal Reproduction Science 124 200-210. (doi:10.1016/j. anireprosci.2010.08.028)

Debrah DO, Novak J, Matthews JE, Ramirez RJ, Shroff SG \& Conrad KP 2006 Relaxin is essential for systemic vasodilation and increased global arterial compliance during early pregnancy in conscious rats. Endocrinology 147 5126-5131. (doi:10.1210/en.2006-0567)

Downing SJ \& Sherwood OD 1985 The physiological role of relaxin in the pregnant rat. I. The influence of relaxin on parturition. Endocrinology 116 1200-1205. (doi:10.1210/endo-116-3-1200)

Downing SJ \& Sherwood OD 1986 The physiological role of relaxin in the pregnant rat. IV. The influence of relaxin on cervical collagen and glycosaminoglycans. Endocrinology 118 471-479. (doi:10.1210/endo118-2-471)

Eldridge RK \& Fields PA 1985 Rabbit placental relaxin: purification and immunohistochemical localization. Endocrinology 117 2512-2519. (doi:10.1210/endo-117-6-2512)

Fields PA \& Fields MJ 1985 Ultrastructural localization of relaxin in the corpus luteum of the nonpregnant, pseudopregnant, and pregnant pig. Biology of Reproduction 32 1169-1179. (doi:10.1095/ biolreprod32.5.1169)

Graubner FR, Reichler IM, Rahman NA, Payan-Carreira R, Boos A \& Kowalewski MP 2017 Decidualization of the canine uterus: from early until late gestational in vivo morphological observations, and functional characterization of immortalized canine uterine stromal cell lines. Reproduction in Domestic Animals 52 (Supplement 2) 137-147. (doi:10.1111/rda.12849)

Griss G, Keck J, Engelhorn R \& Tuppy H 1967 The isolation and purification of an ovarian polypeptide with uterin-relaxing activity. Biochimica et Biophysica Acta (BBA): Protein Structure 140 45-54. (doi:10.1016/00052795(67)90380-7)

Gunzel-Apel AR, Zabel S, Bunck CF, Dieleman SJ, Einspanier A \& Hoppen HO 2006 Concentrations of progesterone, prolactin and relaxin in the luteal phase and pregnancy in normal and short-cycling German Shepherd dogs. Theriogenology 66 1431-1435. (doi:10.1016/j. theriogenology.2006.01.030)

Gunzel-Apel AR, Hoftmann T, Nottorf S, Politt E, Meyer-Lindenberg A, Hoppen HO, Einspanier A, Knijn HM \& Mischke R 2009 Influence of progesterone withdrawal on pregnancy-related parameters during post-implantation early pregnancy loss. Reproduction in Domestic Animals 44 (Supplement 2) 174-181. (doi:10.1111/j.14390531.2009.01381.x)

Hisaw FL 1926 Experimental relaxation of the pubic ligament of the guinea pig. Experimental Biology and Medicine 23 661-663. (doi:10.3181/00379727-23-3107)

Hoffmann B, Hoveler R, Nohr B \& Hasan SH 1994 Investigations on hormonal changes around parturition in the dog and the occurrence of pregnancy-specific non conjugated oestrogens. Experimental and Clinical Endocrinology 102 185-189. (doi:10.1055/s-0029-1211280)

Hombach-Klonisch S, Seeger S, Tscheudschilsuren G, Buchmann J, Huppertz B, Seliger G, Fischer B \& Klonisch T 2001 Cellular localization of human relaxin-like factor in the cyclic endometrium and placenta. Molecular Human Reproduction 7 349-356. (doi:10.1093/ molehr/7.4.349)

Hsu SY, Nakabayashi K, Nishi S, Kumagai J, Kudo M, Sherwood OD \& Hsueh AJ 2002 Activation of orphan receptors by the hormone relaxin. Science 295 671-674. (doi:10.1126/science.1065654)

Hwang JJ, Lee A, Fields PA, Fields P, Haab LM, Haab L, Mojonnier LE, Mojonnier LF, Sherwood OD \& Sherwood OD 1991 Monoclonal antibodies specific for rat relaxin. V. Passive immunization with monoclonal antibodies throughout the second half of pregnancy disrupts development of the mammary apparatus and, hence, lactational performance in rats. Endocrinology 129 3034-3042. (doi:10.1210/endo129-6-3034)

Kautz E, de Carvalho Papa P, Reichler IM, Gram A, Boos A \& Kowalewski MP 2015 In vitro decidualisation of canine uterine stromal cells. Reproductive Biology and Endocrinology 13 85. (doi:10.1186/s12958015-0066-4)

Khaligh HS 1968 Inhibition by relaxin of spontaneous contractions of the uterus of the hamster in vitro. Journal of Endocrinology 40 125-126. (doi:10.1677/joe.0.0400125)

Klonisch T, Hombach-Klonisch S, Froehlich C, Kauffold J, Steger K, Steinetz BG \& Fischer B 1999 Canine preprorelaxin: nucleic acid sequence and localization within the canine placenta. Biology of Reproduction $\mathbf{6 0}$ 551-557. (doi:10.1095/biolreprod60.3.551)

Kowalewski MP, Mason JI, Howie AF, Morley SD, Schuler G \& Hoffmann B 2006a Characterization of the canine 3beta-hydroxysteroid dehydrogenase and its expression in the corpus luteum during diestrus. Journal of Steroid Biochemistry and Molecular Biology 101 254-262. (doi:10.1016/j.jsbmb.2006.06.029)

Kowalewski MP, Schuler G, Taubert A, Engel E \& Hoffmann B $2006 b$ Expression of cyclooxygenase 1 and 2 in the canine corpus luteum during diestrus. Theriogenology 66 1423-1430. (doi:10.1016/j. theriogenology.2006.01.039)

Kowalewski MP, Beceriklisoy HB, Aslan S, Agaoglu AR \& Hoffmann B 2009 Time related changes in luteal prostaglandin synthesis and steroidogenic capacity during pregnancy, normal and antiprogestin induced luteolysis in the bitch. Animal Reproduction Science 116 129-138. (doi:10.1016/j. anireprosci.2008.12.011)

Kowalewski MP, Beceriklisoy HB, Pfarrer C, Aslan S, Kindahl H, Kucukaslan I \& Hoffmann B 2010 Canine placenta: a source of prepartal prostaglandins during normal and antiprogestin-induced parturition. Reproduction 139 655-664. (doi:10.1530/REP-09-0140)

Kowalewski MP, Meyer A, Hoffmann B, Aslan S \& Boos A 2011a Expression and functional implications of peroxisome proliferatoractivated receptor gamma (PPARgamma) in canine reproductive tissues during normal pregnancy and parturition and at antiprogestin induced abortion. Theriogenology 75 877-886. (doi:10.1016/j. theriogenology.2010.10.030)

Kowalewski MP, Michel E, Gram A, Boos A, Guscetti F, Hoffmann B, Aslan S \& Reichler I 2011b Luteal and placental function in the bitch: spatio-temporal changes in prolactin receptor (PRLr) expression at dioestrus, pregnancy and normal and induced parturition. Reproductive Biology and Endocrinology 9 109. (doi:10.1186/1477-7827-9-109)

Lee AB, Hwang JJ, Haab LM, Fields PA \& Sherwood OD 1992 Monoclonal antibodies specific for rat relaxin. VI. Passive immunization with monoclonal antibodies throughout the second half of pregnancy disrupts histological changes associated with cervical softening at parturition in rats. Endocrinology 130 2386-2391. (doi.10.1210/en.130.4.2386)

Longo M, Jain V, Vedernikov YP, Garfield RE \& Saade GR 2003 Effects of recombinant human relaxin on pregnant rat uterine artery and 
myometrium in vitro. American Journal of Obstetrics and Gynecology 188 1468-1474; discussion 1474-1466. (doi:10.1067/mob.2003.454)

MacLennan AH, Grant P, Ness D \& Down A 1986 Effect of porcine relaxin and progesterone on rat, pig and human myometrial activity in vitro. Journal of Reproductive Medicine 31 43-49.

Min G \& Sherwood OD 1996 Identification of specific relaxin-binding cells in the cervix, mammary glands, nipples, small intestine, and skin of pregnant pigs. Biology of Reproduction 55 1243-1252. (doi:10.1095/ biolreprod55.6.1243)

Nara BS, Welk FA, Rutherford JE, Sherwood OD \& First NL 1982 Effect of relaxin on parturition and frequency of live births in pigs. Journal of Reproduction and Fertility 66 359-365. (doi:10.1530/jrf.0.0660359)

Nishiyama T, Tsumagari S, Ito M, Kimura J, Watanabe G, Taya K \& Takeishi M 1999 Immunohistochemical study of steroidogenic enzymes in the ovary and placenta during pregnancy in the dog. Anatomia, Histologia, Embryologia 28 125-129. (doi:10.1046/j.1439-0264.1999.00170.x)

Novak J, Danielson LA, Kerchner LJ, Sherwood OD, Ramirez RJ, Moalli PA \& Conrad KP 2001 Relaxin is essential for renal vasodilation during pregnancy in conscious rats. Journal of Clinical Investigation $\mathbf{1 0 7}$ 1469-1475. (doi:10.1172/JCl11975)

O'Day-Bowman MB, Winn RJ, Dziuk PJ, Lindley ER \& Sherwood OD 1991 Hormonal control of the cervix in pregnant gilts. III. Relaxin's influence on cervical biochemical properties in ovariectomized hormone-treated pregnant gilts. Endocrinology 129 1967-1976. (doi.10.1210/endo-1294-1967)

Onclin K, Murphy B \& Verstegen JP 2002 Comparisons of estradiol, $\mathrm{LH}$ and FSH patterns in pregnant and nonpregnant beagle bitches Theriogenology 57 1957-1972. (doi:10.1016/S0093-691X(02)00644-1)

Pardo RJ \& Larkin LH 1982 Localization of relaxin in endometrial gland cells of pregnant, lactating, and ovariectomized hormone-treated guinea pigs. American Journal of Anatomy 164 79-90. (doi:10.1002/ aja.1001640108)

Pillai SB, Rockwell LC, Sherwood OD \& Koos RD 1999 Relaxin stimulates uterine edema via activation of estrogen receptors: blockade of its effects using ICI 182,780, a specific estrogen receptor antagonist. Endocrinology 140 2426-2429. (doi:10.1210/endo.140.5.6897)

Porter DG 1971 The action of relaxin on myometrial activity in the guinea-pig in vivo. Journal of Reproduction and Fertility 26 251-253. (doi:10.1530/jrf.0.0260251)

Renegar RH, Cobb AD \& Leavitt WW 1987 Immunocytochemical localization of relaxin in the golden hamster (Mesocricetus auratus) during the last half of gestation. Biology of Reproduction 37 925-934. (doi:10.1095/biolreprod37.4.925)

Satchell L, Glister C, Bleach EC, Glencross RG, Bicknell AB, Dai Y, Anand-Ivell R, Ivell R \& Knight PG 2013 Ovarian expression of insulinlike peptide 3 (INSL3) and its receptor (RXFP2) during development of bovine antral follicles and corpora lutea and measurement of circulating INSL3 levels during synchronized estrous cycles. Endocrinology 154 1897-1906. (doi:10.1210/en.2012-2232)

Schafer-Somi S, Aksoy OA, Beceriklisoy HB, Einspanier A, Hoppen HO \& Aslan S 2007 Repeated induction of abortion in bitches and the effect on plasma concentrations of relaxin, progesterone and estradiol-17beta. Theriogenology 68 889-895. (doi:10.1016/j. theriogenology.2007.07.012)

Scott DJ, Rosengren KJ \& Bathgate RA 2012 The different ligand-binding modes of relaxin family peptide receptors RXFP1 and RXFP2. Molecular Endocrinology 26 1896-1906. (doi:10.1210/me.2012-1188)
Sherwood OD 2004 Relaxin's physiological roles and other diverse actions. Endocrine Reviews 25 205-234. (doi:10.1210/er.2003-0013)

Steinetz BG, Goldsmith LT \& Lust G 1987 Plasma relaxin levels in pregnant and lactating dogs. Biology of Reproduction 37 719-725. (doi:10.1095/ biolreprod37.3.719)

Steinetz BG, Goldsmith LT, Harvey HJ \& Lust G 1989 Serum relaxin and progesterone concentrations in pregnant, pseudopregnant, and ovariectomized, progestin-treated pregnant bitches: detection of relaxin as a marker of pregnancy. American Journal of Veterinary Research 50 68-71.

Stoelk E, Chegini N, Lei ZM, Rao CV, Bryant-Greenwood G \& Sanfilippo J 1991 Immunocytochemical localization of relaxin in human corpora lutea: cellular and subcellular distribution and dependence on reproductive state. Biology of Reproduction 44 1140-1147. (doi:10.1095/biolreprod44.6.1140)

Telgmann R \& Gellersen B 1998 Marker genes of decidualization: activation of the decidual prolactin gene. Human Reproduction Update 4 472-479. (doi:10.1093/humupd/4.5.472)

Telgmann R, Maronde E, Tasken K \& Gellersen B 1997 Activated protein kinase $\mathrm{A}$ is required for differentiation-dependent transcription of the decidual prolactin gene in human endometrial stromal cells. Endocrinology 138 929-937. (doi:10.1210/endo.138.3.5004)

Tsutsui T \& Stewart DR 1991 Determination of the source of relaxin immunoreactivity during pregnancy in the dog. Journal of Veterinary Medical Science 53 1025-1029. (doi:10.1292/jvms.53.1025)

Ulutas PA, Musal B, Kiral F \& Bildik A 2009 Acute phase protein levels in pregnancy and oestrus cycle in bitches. Research in Veterinary Science 86 373-376. (doi:10.1016/j.rvsc.2008.09.001)

Unemori EN, Erikson ME, Rocco SE, Sutherland KM, Parsell DA, Mak J \& Grove BH 1999 Relaxin stimulates expression of vascular endothelial growth factor in normal human endometrial cells in vitro and is associated with menometrorrhagia in women. Human Reproduction $\mathbf{1 4}$ 800-806. (doi:10.1093/humrep/14.3.800)

Vannucchi Cl, Mirandola RM \& Oliveira CM 2002 Acute-phase protein profile during gestation and diestrous: proposal for an early pregnancy test in bitches. Animal Reproduction Science 74 87-99. (doi:10.1016/ S0378-4320(02)00160-4)

Vasilenko P, Mead JP \& Weidmann JE 1986 Uterine growth-promoting effects of relaxin: a morphometric and histological analysis. Biology of Reproduction 35 987-995. (doi:10.1095/biolreprod35.4.987)

Wiqvist N 1959 Desensitizing effect of exo- and endogenous relaxin on the immediate uterine response to relaxin. Acta Endocrinologica Supplementum 32 (Supplement 46) 3-14. (doi.10.1530/ acta.0.xxxiis003)

Zhao L, Roche PJ, Gunnersen JM, Hammond VE, Tregear GW, Wintour EM \& Beck F 1999 Mice without a functional relaxin gene are unable to deliver milk to their pups. Endocrinology 140 445-453. (doi:10.1210/ endo.140.1.6404)

Received 8 March 2017

First decision 10 April 2017

Revised manuscript received 3 June 2017

Accepted 30 June 2017 